\title{
Literature Review and Discussion on Collaborative Decision Making Approaches in Industry 4.0
}

\author{
A. C. Sousa \\ A. F. Bertachini \\ C. Cunha \\ R. Chaves \\ M. L. R. Varela \\ Department of Production and Systems \\ University of Minho \\ Portugal
}

Nowadays, companies are faced with an increasingly higher level of competition while trying to adapt to the exigencies imposed by the Industry 4.0, regarding its usually referred dimensions and pillars, among which one that although is not so often referred is also expressing an increasing visibility and importance, related to collaboration, and more specifically to collaborative decision making and co-working. Thus, in this paper an analysis is carried out regarding the evolution of publications that have been put available over the last decade about collaborative decision making approaches, varying from approaches based on mathematical models up to the application of artificial intelligence and other kind of approaches. Moreover, a discussion about the relation between collaborative decision making, concurrent engineering and Industry 4.0 dimensions is also done.

Keywords: Collaboration, decision making approaches, mathematical models, artificial intelligence, concurrent engineering, Industry 4.0.

\section{INTRODUCTION}

Collaboration is a concept that evolved from the concurrent engineering (CE), and has already made history [1-5] but now, in the current I4.0 context [6,7], it is gaining a refreshed importance, for instance under the scope of collaborative decision making (CDM) [6,7], besides the co-working or cooperation paradigm $[8,9]$. Moreover, according to the study by Van Laar et al, in 2017 [10] the so-called 21st-century skills, underlying the I4.0 digitalization era, is a quite extensive list, being not just related to the use of ICT, but further to other core skills, related to technical, information, management, communication, collaboration, creativity, critical thinking and problem solving ones. Thus, it is perceptible that there is a close interrelation between collaboration and I4.0 concepts, namelly related to the application of AI-based approaches and technologies, along with the virtualization and servitization underlying supporting collaborative platforms [11].

There are several kind of approaches, methods and models that have been proposed for supporting decision making processes regarding the resolution of problems occuring in different domains and contexts, for instace for solving industrial engineering and management problems $[6,7]$.

These kind of decision making problems are generally characterized by considering, simultaneously, different options or potential solutions, which have to be considered, generated, analysed, evaluated, and further processed, being usually sorted or negotiated $[12,13]$. Thus a widened set of approaches have been put

Received: January 2021, Accepted: September 2021

Correspondence to: Maria Leonilde Rocha Varela, Department of Production and Systems University of Minho, Portugal

E-mail: leonilde@dps.uminho.pt

doi:10.5937/fme2104817S

(C) Faculty of Mechanical Engineering, Belgrade. All rights reserved forward, varying from purely mathematical models, up to other kind of approaches, namelly based on game therory [14], chaos and complexity management [1517], and a broad range of other kind of approaches, for instance, based on artificial intelligence (AI) approaches and techniques [12,13,18-21].

In fact, CDM can be considered an evolution of the concurrent decision making concept, while establishing the parallelims with the corresponding duple concurrent versus collaborative engineering [1-5].

In the scope of concurrent engineering it is already considered to be of upmost importance to enable, for example, work to be performed simultaneously or in parallel, and to have multidisciplinary teams for carring out decision making processes, in order to enable the confluence of efforts, ideas and solutions, usually based on negotiation processes, to minimize disruptions and errors or inefficiences in work, as well as other concerns along the whole decision making processes, from the project phase up to the work execution, and moreover taking into account other critical aspects underlying the products post-sales extended live cycles and corresponding reengineering issues, among others.

Thus, in fact some of the main characteristics underlying $\mathrm{CDM}$ are inherited from the concurrent engineering paradigm [1-5], along with some of the main pilars or dimensions underlying the I 4.0 concept, mainly regarding the generally used buzz work of "digitalization" [6,7].

Therefore, CDM can be performed through the application of different kind of models, and each of which may be best suited for solving a specific king of problem, and in this paper an overview on mathematical models, artificial intelligence based approaches, among others are analysed, for instance the evolution of its use during the last decade, characterized by the I4.0 era, based on a review carried out through the b-on platform, 
which includes publications from the Scopus and the Web of Science databases.

In order to clearly present and describe the intended content of this paper it will be structured as follows:

Next, in section 2, CDM approaches based on mathematical models, AI-based approaches and other kind or approaches are briefely desceibed. In section 3 a sintesis of the state of the art regarding the evolution of the number of publications put forward during the last decade about CDM is presented. In section 4 a general discussion about the relation between CDM, concurrent engineering and I4.0 is performed. Finally, in section 5 the main conclusions are presented, and planed future work.

\section{COLLABORATIVE DECISION MAKING}

Traditional engineering is characterized by sequential phases, whose activities are only carried out after the approaval and completion of previous activities [1]. However, Concurrent Engineering (CE) consists on an evolution of the sequencial engineering while integrating parallelism between the set of main manufacturing phases from the design cycle of a given product, up to its production, and delivery, and abroad, which did enable to very significantly reduce time and thus cost, through the anticipation of activities, and prevent from the occurrence of potential problems in beforehand, while considering reduzing lengthy approval cycles [1-5].

Concurrent Engineering is thus defined as "a systematic approach to the integrated and concurrent development of a product and its processes, including manufacturing and supplies" [1-5]. The CE is intended to motivate developers to consider all elements of the product lifecycle, from design to disposal, including quality, costs, planning and user requirements [3].

Collaborative decision making, besides, does not just require the main issues underlying the concurrent engineering but additionally approaches and technologies that permit different kind of collaboration, which may vary from purelly human-human $(\mathrm{H}-\mathrm{H})$ interactions up to machine-machine (M-M) ones or be of a hybrid human-machine (H-M) type $[1,3,7,11]$.

Currently, there are many ways to perform CDM, for instance by using approaches based on group decision making processes, which usually require the use of some kind of technique, among an extended set of ones that enable the classification and prioritization of the best alternatives presented by a group of individuals. Thus, group decision-making can be done through: voting, ranking, autocratic decisions, decision analysis involving multiple criteria, and combinations of these kind of approaches, among others.

Although, as there are no perfect approaches, group decision-making processes do also have some drawbacks, as it turns out to be necessary to apply techniques that promote and enrich the creative capacity of a group, for being possible to understand, and prevent problems and, therefore, reach better results.

Therefore, it is of upmost importance to constantly develop and use improved collaborative decision making approaches, and there is already a widened set of models, methods, techniques and tools available to serve this purpose, such as: based on a variety of mathematical models, and on artificial intelligence, among a widened set of other kind of models and approaches, as will be briefely described next.

\subsection{Mathematical models}

There are several kind of mathematical models and methods to support decision making processes applied to solve problems in different contexts, such as for collaboratively solving industrial engineering and management ones.

Multi-criteria methods stand out from the rest, which are characterized by considering, simultaneously, different criteria in the analysis of a situation with different alternatives.

Another theory with a high potential for collaborative decision-making processes is Game Theory. However, its application does not provide solutions in a maximized or minimized way, similar to multi-criteria solutions, but a solution that takes into account the different interests of the agents involved.

Next, a set of different aproaches among the most popular ones are very briefely described.

Analythic Hierarchical Process (AHP) is one of the main mathematical methods applied to support decision making, where several variables or criteria are considered in the selection of only one alternative among the proposals. Based on a scientific methodology, the method allows to analyse, determine and decide the criteria that will influence decision making - more than determining the best alternative, the method allows to justify the choice in a consistent and coherent way. This method was developed in 1970 by Thomas Saaty [22], having been one of the first multicriteria methods to be created. One of the main features that sets it apart from the rest of the methods is its ability to convert empirical data into mathematical models. According to Saaty [22], the AHP method takes advantage of the human capacity to make judgments so that, even when two variables are incomparable, it is possible, with people's knowledge and experience, to recognize which of the criteria is more important.

The VIKOR method, which means "Multi-criteria Optimization and Commitment Solution" [23], was developed to solve decision making problems with several criteria (MCDM), including discordant and noncommensurate criteria - that are not expressed in the same unit. This method focuses on the elaboration of a ranking based on a set of contradictory criteria alternatives, which presents a multi-criteria classification based on the special measure of proximity to the ideal solution.

The Shapley's values consists on a method of coalition game theory that tells us how to fairly distribute the "payment" between resources. In order for agents to assess their prospects for playing a super-additive game, Shapley proposed a value, in which agents receive a reward equal to its value. More specifically, Shapley argued that a coalition of $\mathrm{n}$ agents can be formed from $\mathrm{n}$ ! different ways (considering all possible union orders) and that, in each order, as an agent enters the coalition, 
it contributes marginally to the agents who joined it [14].

The DEMATEL model (Decision Making Trial and Evaluation Laboratory) was applied, for the first time, by Fontela and Gabus in 1971, being a method that allows obtaining quantitative interrelationships between multiple factors, necessary to solve a problem [24]. DEMATEL analyses the dependencies between factors in order to elaborate cause-effect relationships between the criteria and clusters through the creation of a hierarchy or network. This model results in the construction of the cause-effect relationship diagram, where it is possible to visualize, in a clearer way, the complex cause-effect relationships, and to make the appropriate decisions recognizing the criteria involved and their influence on the problem [24].

The TOPSIS (Technique for Order Preference by Similarity to Ideal Solution) is a technique for evaluating the performance of alternatives through similarity with the ideal solution, initially developed by Ching-Lai Hwang and Yoon (1981), by Yoon (1987), and Hwang, Lai and Liu (1993) [25]. According to this technique, the alternative chosen should be the one that is the shortest distance from the positive ideal solution, and, consequently, the largest distance from the negative ideal solution. Thus, the ideal positive solution is a solution that maximizes the benefit criteria and minimizes the cost criteria, in contrast to the ideal negative solution that maximizes the cost criteria and minimizes the benefit criteria.

Chaos and complexity management are presented as "new sciences" and new paradigms that are significantly changing the way scientists understand the functioning of the world. Chaos theory has helped scientists to describe and explain the behaviour of complex, dynamic, non-linear, co-creative and out-of-balance systems (...) [15]. And complexity the emerging field of research that explores systems in which: "many independent agents are interacting with each other in various ways, (...) systemic interactions can lead (...) to spontaneous self-organization" [17]. In this way, complexity helps in understanding how an organization should change to deal with complex and unpredictable environments, enabling change, chaos and the organization and, therefore, establishes new reference structures in and for strategic and organizational management improvement [116].

The PROMETHEE (Preference Ranking Organization Method for Enrichment Evaluation) methods [26], as the name implies, consist of an outranking approach, that consists on the construction and exploration of relationships between alternatives that represent the preferences of the decision makers involved in the problem. With regard to these methodologies, the growth in their application was due to the ease in understanding the concepts and inherent parameters, something that simplifies the process of modelling preferences. In addition, these methods can be easily implemented in a computer language. Each criterion is assigned a preference function, which describes the change in preference of the decision maker according to the difference between the performance levels of two alternatives in the same criterion [26].
Nash Equilibrium was defined in 1950, by John Nash being a remarkable work that did enabke to define and characterize a sense of balance for games in person. This notion, now called "Nash equilibrium", belongs to the so called game therory, and has been widely applied and adapted in economics and other behavioural sciences [27].

A Nash equilibrium is a set of strategies, one for each of the $\mathrm{n}$ players in a game, which has the property that the choice of each player is his best response to the choices of the other n-1, so that one would survive to an ad test, for example: if all players announced their strategies simultaneously, no one would reconsider their move.

\subsection{Al-based approaches}

Artificial Intelligence (AI) has helped companies to solve complex problems, through computers that learn by themselves from previous situations, analysing a large volume of data to generate intelligent recommendations that support a decision. Bearing this in mind, next some approaches based on AI, including some meta-heuristics will be briefely presented.

Probabilistic relational model (PRM) or a relational model of probability [18], uses the mathematical language for the representation and manipulation of uncertainty, whose probabilities are specified in the relationships. This model has demonstrated an important role in the analysis of scientific data, Machine Learning, robotics, cognitive science and artificial intelligence. Probabilistic modelling provides a framework for understanding what learning is and, therefore, has emerged as one of the main theoretical and practical approaches for designing machines that learn from the data acquired through experience. In this way, a machine can use these models to make predictions about future data and make decisions that are rational, according to those predictions [18].

When investigating the Machine Learning probabilistic approach, Ghahramani, in 2015 [18] pointed out that although conceptually simple, the approach presents several computational and modelling challenges, the main computational challenge being the fact that learning involves the sum of all model variables.

Smart contracts were characterized by Angelis and Silva through the relationship between AI and Blockchain in their study in 2019 [28]. According to the authors, although the two technologies are different, their combined use enables to solve complex problems. AI allows computers to learn from accessible data, while blockchain provides collaborative data accuracy, which is useful for feeding data into the AI system, and recording its output. In short, a traceable path not only improves data reliability and model building, but also creates a route back to the automated decision-making process. AI makes decisions that are stored on the Blockchain. This is returned to the AI to allow for further analysis and to improve decision making.

Ant Colony Optimization (ACO) is, as the name suggests, a technique inspired by the natural behaviour of ant colonies used to solve combinatorial optimization problems - when ants feed, they naturally seem to find a 
"logical" route and "effective" between the nest and the food source - in other words, the ants seem to determine an ideal route, following an organized and intelligent technique. Thus, the ACO, developed by Stützle \& Dorigo in 1999 [13], is an iterative algorithm based on this behaviour belonging to the class of metaheuristics. The details of this technique are modelled using mathematical tools and then there is a transformation of the approach into a structure of optimization problems used to solve them.

The Particle Swarm Optimization (PSO) was introduced by James Kennedy and Russell Elberhart in 1995 [14] to solve problems in the continuous domain. The PSO is derived from an experimental algorithm that models social behaviour observed in many groups of birds, and the particles are the individuals of the population.

Since individuals are members of a society, they also understand the behaviour of their neighbours. There are two types of information that correspond to personal learning - cognitive and cultural - social delivery. Therefore, the likelihood that a particular individual will make a specific decision will depend on past performance and the performance of certain neighbours.

The Fuzzy Multi-Criteria Group Decision Making was introduced in 1965 by Lofti Zadeh [15] through the fuzzy set theory (a set of fuzzy numbers), a theory in which everything is a matter of degree, as a way of numerically representing uncertainties, values and real opinions.

For this, Zadeh used the notion of binary association to contain various degrees of association in the real continuous interval $[0,1]$, where the extremes 0 and 1 represent, respectively, "without association" and "total association", for achieving a more realistic way to represent human knowledge. Thus, the main objective of fuzzy logic is to express how much an alternative satisfies a certain criterion according to the elaborated binary association.

For this, it is necessary to approach this method according to the fuzzy inference system, which consists of making a decision based on a set of variables and rules.

\subsection{Other approaches}

There are many other kind of approches for supoorting CDM, based on different types of models that have been put forward since early 40's, and some of the most wellknown are briefely described below.

The McGrath model is a model proposed by McGrath in 1984 [29], and integrates a classification scheme for tasks performed by a group. It is based on a graph with two axes, a horizontal one referring to the cognitive/ behavioural dimension, and a vertical one that defines the tasks in relation to conflict/ collaboration. These axes are used to describe the tasks and behaviours required to perform them. In addition, the graph is divided into four quadrants, which correspond to the four major processes: generating (alternatives or plans); choose (a correct answer or a solution), negotiate (resolve conflicts of interest or points of view), and execute (in competition with an opponent, or in competition against external measures.

The DeSanctis and Gallupe model was proposed by DeSanctis and Gallupe, in 1987 [30], and represents a multidimensional taxonomy based on three dimensions considered important: the size of the group, the proximity and the nature of the task. The first dimension considered by these authors is the size of the group. In this model the number of members is an important factor in group decisions, because the greater the number of participants, the greater the amount of information that is generated and the less the frequency, duration and intimacy of information exchanges between group members. Another dimension to take into account is the proximity between group members during a meeting, and it can be measured in terms of both space and time. Meetings can be held face-to-face or remotely. The third dimension of this taxonomy is the type of task that the group decision intends to perform. According to this dimension, group decisions can present 6 different types of tasks. And these six tasks can be further grouped into 3 types of different objectives [30].

The Toulmin [argumentation] model is a model devoloped in 1984, by Touling et al [31], through which people or groups of prestige value the acts. The person's value, previously recognized, constitutes the premise from which a conclusion will be drawn recommending a particular behaviour [31]. To serve as a model, a minimum of prestige is required. Sometimes it is a model to be followed by a small group, sometimes it is a pattern to be followed in certain circumstances.

The Anarchic model is a Default Decision Template that was proposed by Cohen, March and Olsen in 1972 [32] that coined the term "trash can" to describe a model in which the decision-making process has no defined rules and can even be inconsistent. In this model, the organization is not in harmony with the situation experienced, because the problems and solutions are taken by the decision makers and "the decisions result from the encounter of independent currents of problems, solutions, participants and situations of choice" [32].

The Rational Decision Making Model: was developed by Cyert, March and Simon in 1963 [33]. Among the various existing models, this model is the most systematized and structured one, since it presupposes pre-defined rules and procedures that, in turn, must be followed in order to achieve a good result. Thus, the rational model prevails in closed systems, where the organizational structure is quite bureaucratic and the organization's guidelines are defined through formal rules. The key questions of the rational model are: What is the problem? What are the alternatives? What are the costs and advantages of each alternative? What should be observed as a standard for making decisions in similar situations?

The Political model consists on a decision-making process through which decision-making is the result of a series of activities, in which the decision-maker has different objectives and generally has the greatest political advantage. During this process, a power structure is permanently changed through the following 
strategies: creating groups, using information, collaborating and seeking external resources [34].

The Incremental model was proposed by Lindblom in 1958 [35]. It examines the decision-making process from a political perspective. The model deviates fundamentally from the rational model: the choice of decisions is made without specifying goals or values in advance, specific actions are discussed, and each action attributes the actions to the goals and values that it perceives or expects. Therefore, the criteria for choosing an action are related to the degree of consensus it generates, and not to its contribution to the fulfilment of existing goals. This model, as the name implies, involves a "policy of small steps", without the drastic changes of the rational model. Decision makers look for a satisfactory result, more than for achieving ideal situations, and accept the possibility of continuous review of the actions taken.

The Organic Model is based on the integrated organic information management system model, pro-posed by Rosseau and Couture in 1998 [36]. It aims to collaborate with the organizational decision-making process and to define the managers responsible for this task so important for any type of organization. In this decision-making model, organic information is the key element.

The Limited Rationality Model, also known as bound rationality, is a concept proposed by Herbert Simon that is called "limited" or "bounded", because there are limits to our ability to think, available information and time. Limited rationality is a central assumption of the "natural assessments" view of heuristics and dual-system thinking models, and is one of the psychological foundations of behavioural economics [37].

The Kepner-Tregoe Problem Solving and Decision Making was founded by Charles Kepner and Benjamin Tregoe that developed a rational working method in the 1960s [38], in which they researched and identified people's skills in solving problems. In doing so, they laid the foundation for effective teamwork, teaching the people involved to consciously use the four basic set of patterns that they already use unconsciously. These four basic patterns of thinking are reflected in the four types of questions that managers ask every day: "What's going on?", "Why did this happen?", "What course of action should we take?", "What's next? [38].

The Behavioural Model is a theoretical model based on people's individual behaviour and seeks to explain how people behave, studying human motivation [39]. The authors verified that the administrator needs to know the human needs for better understanding human behaviour and use human motivation as a powerful means to improve the quality of life within organizations. The behavioural approach - also called behaviourist (due to behaviourism in psychology) - marks the strongest influence of behavioural sciences on administrative theory and the search for new democratic, human and flexible solutions to organizational problems [39].

The Procedural Model was developed by Mintzberg, Raisinghani and Théorêt in 1976 [40], and despite the similarities with the rational model, the procedural model has an important differentiating factor
- the condition of flexibility - that allows managers to make adjustments when necessary. This model is used when the objectives are clear, but the methods and techniques to achieve them are not, something that can lead to interruptions and repetitions when the decisionmaking process starts. Even so, the process reveals a general line of development whose beginning coincides with the recognition and diagnosis of a problem, proceeding to an analysis of the alternatives, culminating in an evaluation and selection of one among the various options in order to solve the problem. This model focuses on obtaining long-term results, follows a strategic orientation, aims to promote changes, and is diversified, which make it an example of how interdisciplinary decision-making occurs.

The Creative Problem Solving (CPS) is a method of supporting group decision making that allows for an innovative, creative and imaginative approach for solving a problem or challenge. There are different variations of the CPS model, which derive from the work started by Alex Osborn in the 1940s, developed jointly with Sid Parnes in the 1950s and, later promoted by the University of Buffalo and the Creative Education Foundation [41]. Currently, according to the Creative Education Foundation, the Osborn-Parnes Creative Problem Solving process comprises 2 assumptions, assuming that, in some way, everyone is creative, and that creative skills can be learned and improved.

The Drexler-Sibbet Team Performance Model is a model that illustrates the development of the team in seven stages, in the first four stages teams are created and the last three stages are dedicated to "Sustaining the team performance". To develop and maintain teams, this tool can be used as a common structure and language to support a team-based culture, or it can be used with the online team assessment tool. This model is composed of seven stages: orientation, confidence building, clarification of goals, commitment, implementation, high performance and renewal [42].

The Diamond of Participatory Decision-Making, according to Sam Kaner and colleagues in the community at work in 2007 [43], team investment is an important factor in agile software development and can be strengthened by providing the team with space for collective decision-making. Team employees can provide guidance and training where appropriate. The Team Performance model. The diamond is a schematic representation of the different stages in the time that a team needs to move to develop a solution that is satisfactory for everyone. In the Diamond of Participatory Decision-Making model there are five different stages: Business as usual, Divergent zone, Groan zone, Convergent zone and Closure zone [43].

\section{STATE OF THE ART ANALYSIS}

\subsection{Mathematical models}

A varying amount of different kind of mathematical models, e.g. [44-47] have been put forward during the last decade, as summarized in Figures 1 and 2.

Through the analysis of this Figures 1 and 2 it is possible to realise that mathematical models based on 
the AHP and the TOPSIS methods have been the most frequently applied to solve decision making problems in the focused domain, followed by the VIKOR model and also by models based on chaos and complexity analysis.

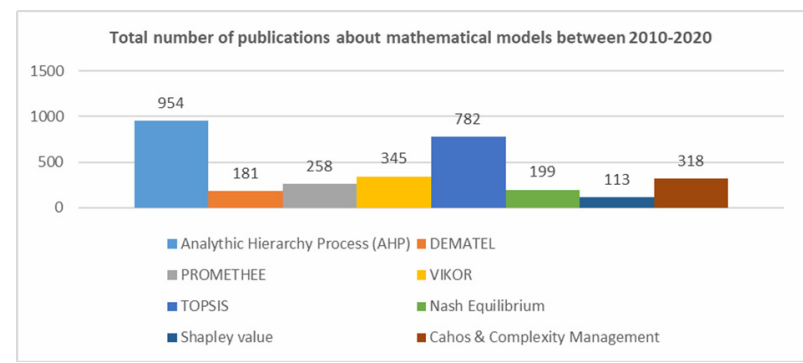

Figure 1. Publications about mathematical models.

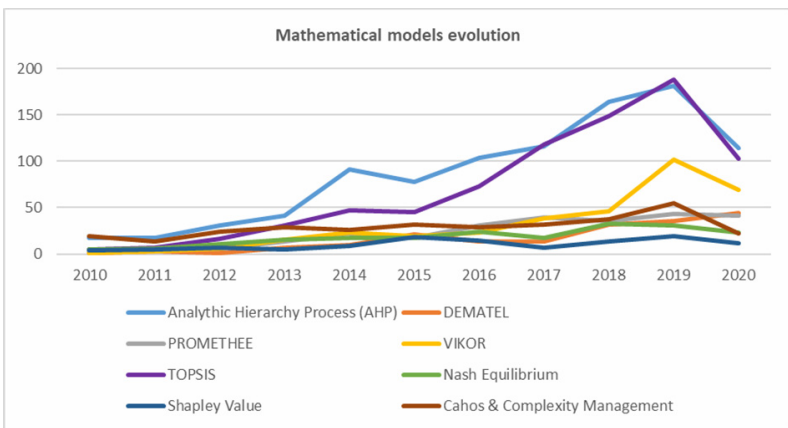

Figure 2. Evolution of mathematical models.

\subsection{Al-based approaches}

The application of AI-based approaches has also evolved over the last decade, and meta-heuristics based approaches have been widely used, for instance based on ACO and PSO, as can be observed through Figures 3 and 4.

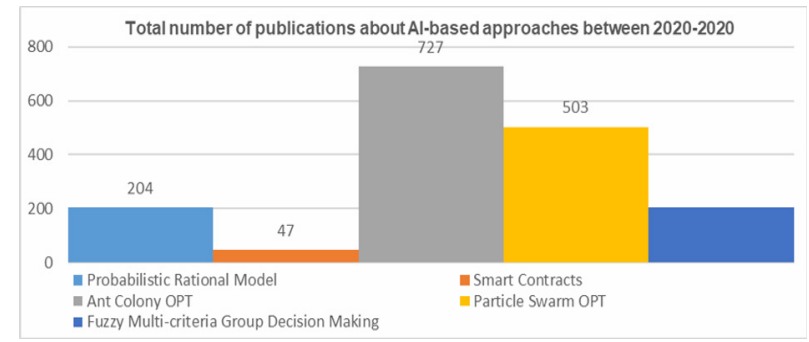

Figure 3. Publications about Al-based approaches.

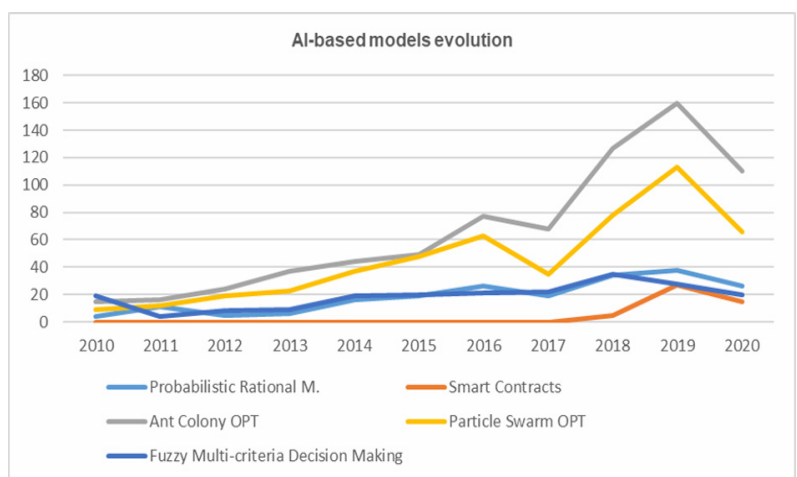

Figure 4. Evolution of Al-based approaches.

Besides, PRM and machine learing based approaches have also acquiring growing importance, as well as fuzzy multi-criteria group decion-making, mainly since 2017, while smart contract are getting more attention more recently, after 2018 .

\subsection{Other approaches}

Besides de application of mathematical models and AIbased approaches other kind of approaches have been applied for solving decion making problems, regarding CDM, during the last decade, being the most popular one the Diamond of participation (456), followed by the Political model (259), and by the Limited Rationality (202), the Toulim (201), and the Organic (178) models. Altough, regarding this last one, as it can be noticed through the Figure 6, it had a big application between 2010 and 2013, but did experience a sharp decrease of application during the following years.

\section{DISCUSSION}

The CDM concepts does, in fact, inherit characteristics from the concurrent engineeing, and from the I4.0 ones, as is illustrared through Figure 7, and expressed in Table 1.

Through the analysis carried out in this study, along with the own knowledge and expertise of co-authors in this field of knowledge it stands out that CDM approaches imply requisits, from the list below, which are further related with CE and I4.0.

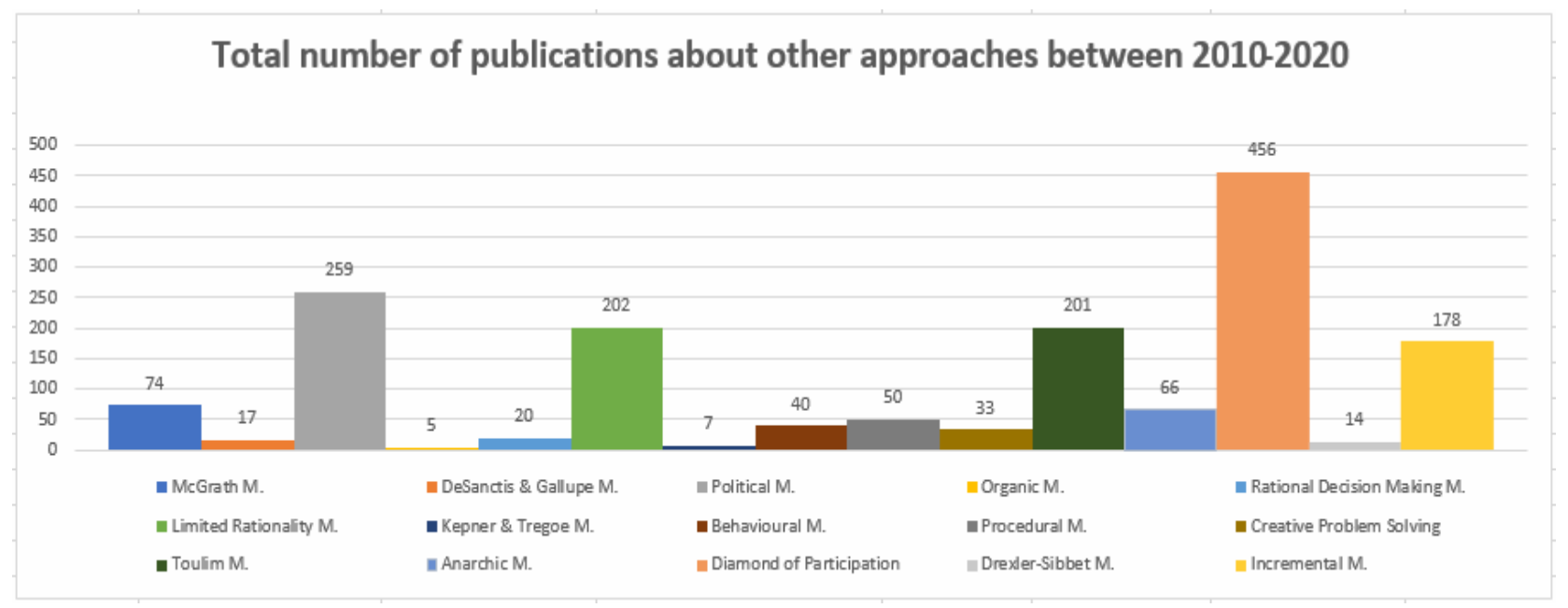

Figure 5. Publications about other approaches 


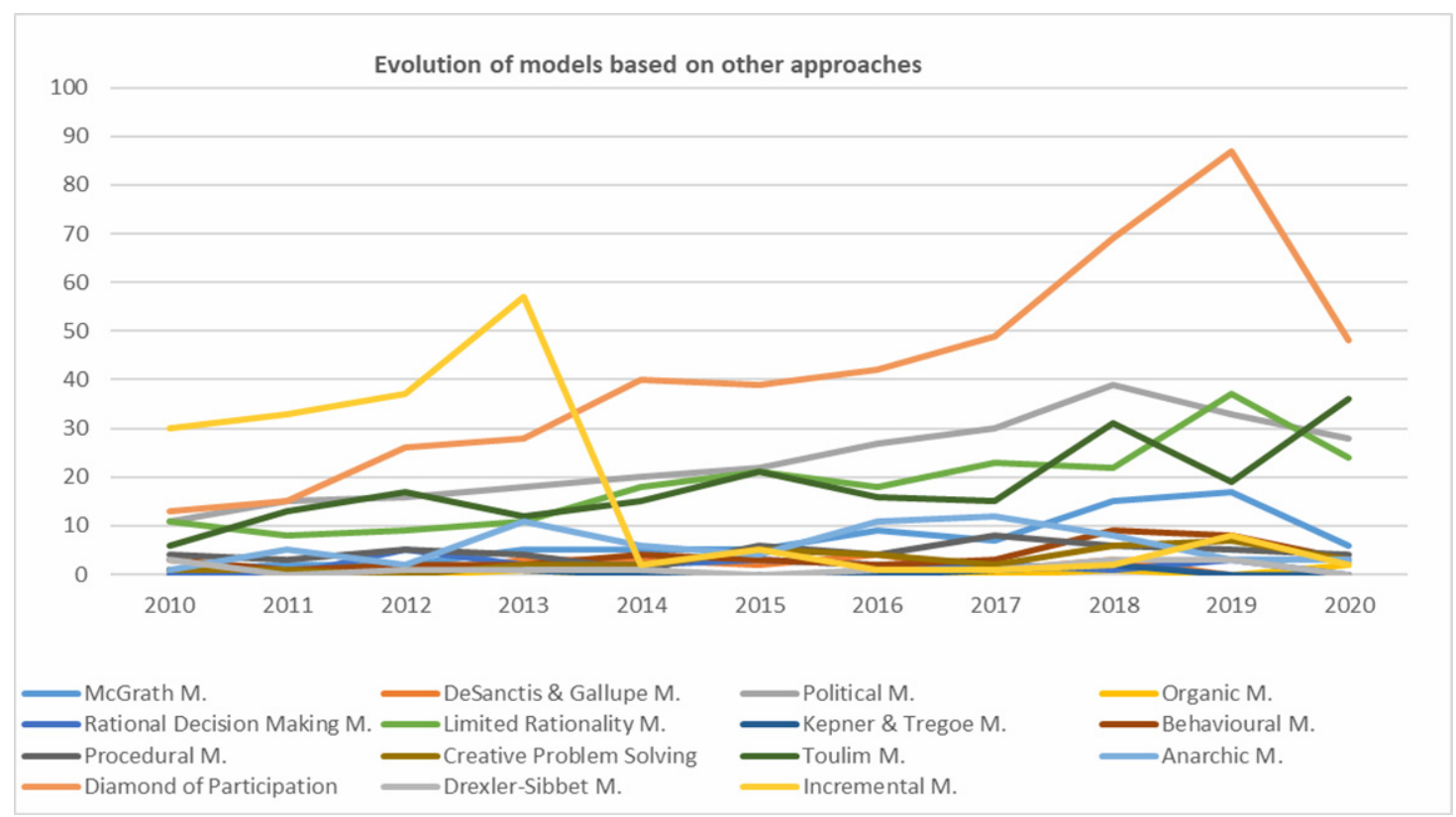

Figure 6. Evolution of other approaches.

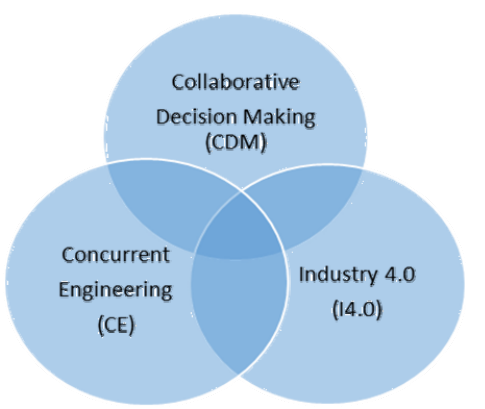

Figure 7. Relation between CMD, CE and 14.0.

\section{Table 1. Main characteristics underlying CDM in CE and} 14.0

\begin{tabular}{|l|l|}
\hline 1. Sharing & 11. Uncertainty \\
2. Co-creation & management \\
3. Negotiation & 12. Intelligence \\
4. Learning & 13. Distribution \\
5. Group decision making & 14. Decentralization \\
6. Integration & 15. Parallelism \\
7. Networking & 16. Digitalization \\
8. Dinamism and agility & 17. Automation \\
9. Human-centrism & 18. Self-organization \\
10. Multi-criteria & 19. Real-time processing \\
\hline
\end{tabular}

Thus, in fact some of the main characteristics underlying collaborative enginerring and, in this particular scope, the $\mathrm{CDM}$ are inherited from the concurrent engineering paradigm [1-5] along with its relation with some of the main pilars or dimensions underlying the $I 4.0$ concept $[6,7]$ mainly regarding the generally used buzz work of "digitalization", but also, and more specifically, regarding the requisits underlying: integration, networking, dynamism and agility, uncertainty management, intelligence (AI), distribution, decentralization, parallelism, automation, self-organization, and real time processing.

Although, and as previously refered, what clearly enables to distinguish the collaboration paradigm from the concurrent engeneering, and consequently CDM is learning, which thus constitutes its fundamental pillar, but which, of course, is also inherent to the I4.0.

Moreover, although the human-centrism is also one of the main characteristics of CDM, there do also exist other kind of collaboration, and thus CDM approaches, based on human-machine, and machine-machine collaborations $[3,12,13]$. Therefore, a widened set of approaches and underlying technologies, such as based on multi-criteria, group decision making, uncertainty management, co-creation, up to intelligent and completely automatic and self-oranizing mechanisms are very relevant in the scope collaboration, e.g. CDM in I4.0, and in Table 2 are summarized the main categories, subcategories, and underlying approaches, along with its level of importane in I4.0, according to the literature review carried out in this work.

Moreover, the number of characteristics summarized in the list shown in Tabl 1, underlying a given CDM approach will much depend on the complexity and or on the level of exigency of the corresponding problem to be solved.

Table 2. CDM methods and its occurance in $\mathbf{1 4 . 0}$

\begin{tabular}{|c|c|c|c|}
\hline Category & Subcategory & Approach type & $\begin{array}{l}\text { Occurance } \\
\text { level in I4.0 }\end{array}$ \\
\hline \multirow[t]{8}{*}{$\begin{array}{l}\text { Mathematical } \\
\text { Methods }\end{array}$} & $\begin{array}{l}\text { Analythica } \\
\text { Hierarchical } \\
\text { Process (AHP) }\end{array}$ & $\begin{array}{l}\text { MCDM } \\
\text { (one of the first } \\
\text { ones) }\end{array}$ & $15 \%$ \\
\hline & $\begin{array}{l}\text { VIKOR } \\
\text { method }\end{array}$ & MCDM & $5 \%$ \\
\hline & $\begin{array}{l}\text { The Shapley's } \\
\text { values }\end{array}$ & Game theory & $2 \%$ \\
\hline & $\begin{array}{l}\text { The } \\
\text { DEMATEL } \\
\text { model }\end{array}$ & $\begin{array}{l}\text { Cluster analysis } \\
\text { in a network }\end{array}$ & $3 \%$ \\
\hline & The TOPSIS & $\begin{array}{l}\text { Similatirty based } \\
\text { approach }\end{array}$ & $12 \%$ \\
\hline & $\begin{array}{l}\text { Chaos and } \\
\text { complexity }\end{array}$ & $\begin{array}{l}\text { Chaos and } \\
\text { complexity } \\
\text { approach }\end{array}$ & $5 \%$ \\
\hline & $\begin{array}{l}\text { The } \\
\text { PROMETHEE }\end{array}$ & $\begin{array}{l}\text { Outranking of } \\
\text { agents' } \\
\text { preferences }\end{array}$ & $4 \%$ \\
\hline & Nash & Game theory & $3 \%$ \\
\hline
\end{tabular}




\begin{tabular}{|c|c|c|c|}
\hline & Equilibrium & & \\
\hline \multirow[t]{5}{*}{$\begin{array}{l}\text { AI based } \\
\text { approaches }\end{array}$} & $\begin{array}{l}\text { Probabilistic } \\
\text { relational } \\
\text { model }\end{array}$ & $\begin{array}{l}\text { Probabilistic } \\
\text { uncertainty } \\
\text { approach }\end{array}$ & $3 \%$ \\
\hline & $\begin{array}{l}\text { Smart } \\
\text { contracts }\end{array}$ & Blockchain & $1 \%$ \\
\hline & $\begin{array}{l}\text { Ant Colony } \\
\text { Optimization }\end{array}$ & Metaheuristic & $11 \%$ \\
\hline & $\begin{array}{l}\text { Particle Swarm } \\
\text { Optimization }\end{array}$ & Metaheuristic & $8 \%$ \\
\hline & $\begin{array}{l}\text { Fuzzy Multi- } \\
\text { Criteria Group } \\
\text { Decision } \\
\text { Making }\end{array}$ & $\begin{array}{l}\text { MCDM with } \\
\text { uncertainty } \\
\text { approach }\end{array}$ & $3 \%$ \\
\hline \multirow[t]{15}{*}{$\begin{array}{l}\text { Other } \\
\text { approaches }\end{array}$} & $\begin{array}{l}\text { The McGrath } \\
\text { model }\end{array}$ & Graph theory & $1 \%$ \\
\hline & $\begin{array}{l}\text { The DeSanctis } \\
\text { and Gallupe } \\
\text { model }\end{array}$ & $\begin{array}{l}\text { Multidimensional } \\
\text { taxonomy }\end{array}$ & $0.3 \%$ \\
\hline & $\begin{array}{l}\text { The Toulmin } \\
\text { model }\end{array}$ & $\begin{array}{l}\text { Argumentation } \\
\text { based approach }\end{array}$ & $3 \%$ \\
\hline & $\begin{array}{l}\text { The Anarchic } \\
\text { model }\end{array}$ & $\begin{array}{l}\text { Default decision } \\
\text { template }\end{array}$ & $1 \%$ \\
\hline & $\begin{array}{l}\text { The Rational } \\
\text { Decision } \\
\text { Making Model }\end{array}$ & $\begin{array}{l}\text { Systematized and } \\
\text { structured } \\
\text { approach }\end{array}$ & $0.3 \%$ \\
\hline & $\begin{array}{l}\text { The Political } \\
\text { model }\end{array}$ & $\begin{array}{l}\text { Activity based } \\
\text { decision approach }\end{array}$ & $\mathrm{pu}$ \\
\hline & $\begin{array}{l}\text { The } \\
\text { Incremental } \\
\text { model }\end{array}$ & $\begin{array}{l}\text { Political } \\
\text { prespective based } \\
\text { approach }\end{array}$ & $3 \%$ \\
\hline & $\begin{array}{l}\text { The Organic } \\
\text { Model }\end{array}$ & $\begin{array}{l}\text { Integrated } \\
\text { organic decision } \\
\text { approach }\end{array}$ & $0.1 \%$ \\
\hline & $\begin{array}{l}\text { The Limited } \\
\text { Rationality } \\
\text { Model }\end{array}$ & $\begin{array}{l}\text { Natural } \\
\text { assessment } \\
\text { thinking } \\
\text { approach } \\
\end{array}$ & $3 \%$ \\
\hline & $\begin{array}{l}\text { The Kepner- } \\
\text { Tregoe Model }\end{array}$ & $\begin{array}{l}\text { Patterns } \\
\text { recognition }\end{array}$ & $0.1 \%$ \\
\hline & $\begin{array}{l}\text { The } \\
\text { Behavioural } \\
\text { Model }\end{array}$ & $\begin{array}{l}\text { Behavioural } \\
\text { analysis based } \\
\text { approach }\end{array}$ & $0.6 \%$ \\
\hline & $\begin{array}{l}\text { The Procedural } \\
\text { Model }\end{array}$ & $\begin{array}{l}\text { Structural } \\
\text { analysis based } \\
\text { approach }\end{array}$ & $0.8 \%$ \\
\hline & $\begin{array}{l}\text { The Creative } \\
\text { Problem } \\
\text { Solving }\end{array}$ & $\begin{array}{l}\text { Group decisions } \\
\text { based on creative } \\
\text { analysis }\end{array}$ & $0.5 \%$ \\
\hline & $\begin{array}{l}\text { The Drexler- } \\
\text { Sibbet Team } \\
\text { Performance } \\
\text { Model }\end{array}$ & $\begin{array}{l}\text { Team-based } \\
\text { culture analysis } \\
\text { seven stage } \\
\text { approach } \\
\end{array}$ & $0.2 \%$ \\
\hline & $\begin{array}{l}\text { The Diamond } \\
\text { of Participation }\end{array}$ & $\begin{array}{l}\text { Collective } \\
\text { decision makin } 5 \\
\text { stages approach }\end{array}$ & $7 \%$ \\
\hline
\end{tabular}

Thus, for solving one particular problem or situation it may be sufficient to just consider the use of an approach that uses, for instance a multi-criteria approach based on a group decision making methodology and that is put available through a webbased tool, but in some other more exigent scenarios it may be necessary to use some additional technologies, for instance, some kind of leraning algorithm, to further enable some level of knowledge creation, and thus automation or self-organization capability, for enabling an automated decision making process, which will be considered to be of upmost importance, for instace, while dealing with problems with bid and complex data, and which are becoming quite usual nowadays in the current digitaliztion era, namely occuring in industrial contexts.

For example, a human-centred CDM approach, based on the use of a machine learning algoritm, does usually require the human expertise for providing or filtering considerd "good" or positive examples from "bad" or negative ones, while feeding and guiding the learning process in a machine, thus consisting on an human-machine collaboration, were the human acts as the so called "oracle".

\section{CONCLUSION}

Nowadays, organizations are faced with highly exigent decision-making requirements for instance regarding the necessities driven from the current Industry 4.0 context, thus in this paper the importance of collaborative decision making (CDM) is approached as a way of enabling better decision making processes in I4.0. Moreover, the proposed CDM concept is defined in the context of its predecessor concurrent engineering, besides its contextualization in the scope of the main Industry 4.0 pillars or dimensions.

In this paper the evolution of different kind of decision making approaches were analysed, which were grouped in mathematical models, artificial intelligence based approaches and other approaches. Approaches belonging to these three groups were analysed in terms of the total number of publications over the last decade. According to the results obtained in this study it was found out that the five models most studied and referenced in the last decade were based on: Analytic Hierarchy Process (954), TOPSIS (782), Ant Colony Optimization (727), Particle Swarm Optimization (503) and Diamond of Participation (456). So we can conclude that during the last decade there was a predominance of studies of models based on Mathematics and Artificial Intelligence, when compared to models based on other approaches. Thus, as the AI is one of the most relevant pillars of the $\mathrm{I} 4.0$, it can be concluded that CDM approaches based on AI have been playing an important role currently in the 21 st century, and that most probably this tendency will continue furhter. In therms of future work, it is important to further explore the evolutuion of the analysed and other CDM models, methods, and tools.

\section{ACKNOWLEDGMENT}

This work has been supported by FCT - Fundação para a Ciência e Tecnologia within the R\&D Units Project Scope: UIDB/00319/2020.

\section{REFERENCES}

[1] Putnik, G.D., Putnik, Z., Shah, V., Varela, L., Ferreira, L., Castro, H., Alves, C., Pinheiro, P., Collaborative Engineering definition: Distinguishing it from Concurrent Engineering through the complexity and semiotics lenses. In Proceedings of the International Conference on Axiomatic Design (ICAD 2021), 23-25 June 2021, Lisbon, Portugal. 
[2] Putnik, G.D., Putnik, Z., Shah, V., Varela, L., Ferreira, L., Castro, H., Alves, C., Pinheiro, P., Collaborative Engineering: A Review of Organisational Forms for Implementation and Operation. In Proceedings of the International Conference on Axiomatic Design (ICAD 2021), 2325 June 2021, Lisbon, Portugal.

[3] Putnik, G. D., \& Putnik, Z. (2019). Defining Sequential Engineering, Simultaneous Engineering, Concurrent Engineering and Collaborative Engineering: On similarities and differences. Procedia CIRP, 84, 68-75.

[4] Pithon, A. J. C., \& Putnik, G. D. (2009). BM_Virtual Enterprise Architecture Reference Model for Concurrent Engineering: An experiment. Produto \& Produção, 10(2).

[5] Pennell, J. P., \& Winner, R. I. (1989). Concurrent engineering: practices and prospects. In 1989 IEEE Global Telecommunications Conference and Exhibition' Communications Technology for the 1990s and Beyond' (pp. 647-655). IEEE.

[6] Federal Ministry for Economic Affairs and Energy. Digitization of Industrie - Plattform Industrie 4.0, 2016.

[7] Putnik, G.D., Ferreira, L.G.M. (2019) Industry 4.0: Models, tools and cyber-physical systems for manufacturing (Editorial). FME Transactions, 47(4), 659-662.

[8] Petrillo, A., De Felice, F., Cioffi, R., \& Zomparelli, F. (2018). Fourth industrial revolution: Current practices, challenges, and opportunities. Digital transformation in smart manufacturing, 1-20.

[9] Ustundag, A., \& Cevikcan, E. (2017). Industry 4.0: managing the digital transformation. Springer.

[10] Van Laar, E., Van Deursen, A. J., Van Dijk, J. A., \& De Haan, J. (2017). The relation between 21stcentury skills and digital skills: A systematic literature review. Computers in human behavior, 72, 577-588.

[11]Ferreira, L., Putnik, G. Varela, L., Manupati, V.K., Lopes, N., Cunha, M., Alves, C., Castro, H. A Framework for Collaborative Practices Platforms for Humans and Machines in Industry 4.0 oriented Smart and Sustainable Manufacturing Environments. In Smart and Sustainable Manufacturing Systems for Industry 4.0, Vijaya Kumar Manupati, Goran D. Putnik and Maria Leonilde Rocha Varela (Eds.), CRC Press, Taylor $\&$ Francis Group (in press).

[12] Arrais-Castro, A., Varela, M. L. R., Putnik, G. D., Ribeiro, R. A., Machado, J., \& Ferreira, L. (2018). Collaborative framework for virtual organisation synthesis based on a dynamic multi-criteria decision model. IJCIM, 1-12. Taylor \& Francis.

[13] Campanella, G., Pereira, A., Ribeiro, R. A., \& Varela, M. L. R. (2011). Collaborative dynamic decision making: A case study from B2B supplier selection. In Euro Working Group Workshop on Decision Support Systems (pp. 88-102). Springer, Berlin, Heidelberg.
[14] Maleki, S., Rahwan, T., Ghosh, S., Malibari, A., Alghazzawi, D., Rogers, A., ... \& Jennings, N. R. (2020). The Shapley value for a fair division of group discounts for coordinating cooling loads. PloS one, 15(1), e0227049.

[15] Fitzgerald, L. A., \& van Eijnatten, F. M. (2002). Reflections: Chaos in organizational change. Journal of Organizational Change Management.

[16] van Eijnatten, F. M., \& Putnik, G. D. (2004). Chaos, complexity, learning, and the learning organization. The Learning Organization.

[17] Waldrop, M. M. (1992). Complexity: The Emerging Science at the Edge of Order and Chaos. New York, NY: Simon and Schuster.

[18] Ghahramani, Z. (2015). Probabilistic machine learning and artificial intelligence. Nature, Vol 521, pp. 452-459.

[19] Dorigo, M., Birattari, M., \& Stutzle, T. (2006). Ant colony optimization. IEEE comp. intelligence magazine, 1(4), 28-39.

[20] James Kennedy and Russell Eberhart. Particle swarm optimization. In Proc. of the IEEE Int. Conf. on Neural Networks, vol. IV, 1942-1948, Piscataway, NJ, 1995. IEEE.

[21]Zadeh, L. A. (1965). Fuzzy sets. Inform. and control, 8(3), 338-353.

[22] Saaty, Thomas L. (2008). Decision making with the analytic hierarchy process. Int journal of services sciences, 1.1 (2008): 83-98.

[23] Tong, L. I., Chen, C. C., \& Wang, C. H. (2007). Optimization of multi-response processes using the VIKOR method. The Int. Journal of Advanced Manufacturing Technology, Vol. 31(11-12), 10491057.

[24] Wu, H. H., Chen, H. K., \& Shieh, J. I. (2010). Evaluating performance criteria of employment service outreach program personnel by DEMATEL method. Expert Systems with Applications, 37(7), 5219-5223.

[25]Hwang, C. L., Lai, Y. J., \& Liu, T. Y. (1993). A new approach for multiple objective decision making. Computers \& operations research, 20(8), 889-899.

[26] Brans, J. P., \& De Smet, Y. (2016). PROMETHEE methods. In Multiple criteria decision analysis, 187219. Springer, NY.

[27]Holt, C. A., \& Roth, A. E. (2004). The Nash equilibrium: A perspective. Proceedings of the National Academy of Sciences, 101(12), 39994002.

[28] Angelis, J., \& da Silva, E. R. (2019). Blockchain adoption: A value driver perspective. Business Horizons, 62(3), 307-314.

[29] McGrath, J. E. (1984). Groups: Interaction and performance (Vol. 14). Englewood Cliffs, NJ: Prentice-Hall.

[30]Desanctis, G., \& Gallupe, R. B. (1987). A foundation for the study of group decision support systems. Managem science, 33(5), 589-609. 
[31] Hitchcock, D. (2005). Good reasoning on the Toulmin model. Argumentation, 19(3), 373-391.

[32] Cohen, M. D., March, J. G.,Olsen, J. P. (1972). A garbage can model of organizational choice. Adm. science quarterly, 1-25.

[33] Cyert, R. M., \& March, J. G. (1963). A behavioral theory of the firm. Englewood Cliffs, NJ, 2(4), 169187.

[34] Anastasopoulos, P. G. (1992). Tourism and attitude change: Greek tourists visiting Turkey. Annals of tourism research, 19(4), 629-642.

[35] Lindblom, C. E. (1958). Tinbergen on policymaking. Journal of Political Economy, 66(6), 531538.

[36] Rousseau, L., Couture, M., Dupont, A., Labrie, F., \& Couture, N. (1990). Effect of combined androgen blockade with an LHRH agonist and flutamide in one severe case of male exhibitionism.

[37] Gilovich, T., Griffin, D., \& Kahneman, D. (Eds.). (2002). Heuristics and biases: The psychology of intuitive judgment. Cambridge university press.

[38] Kepner-Tregoe, Inc. (1979). Problem analysis and decision making.

[39] Chiavennato (2001) Introducción a la Teoría General de la Administración, 5ta edición. Méjico C.

[40] Mintzberg, H., Raisinghani, D., \& Theoret, A. (1976). The structure of unstructured decision processes. Adm science quarterly, 246-275.

[41] Henshon, S. E. (2006). Creative exploration: an interview with Don Treffinger.

[42] Drexler, A. B., Sibbet, D., \& Forrester, R. H. (1988). The team performance model. Team building: Blueprints for productivity and satisfaction, 45-61.

[43] Kaner, S. (2014). Facilitator's guide to participatory decision-making. John Wiley \& Sons.

[44] Arrais-Castro, A., Varela, M. L. R., Ribeiro, R. A., Putnik, G. D. (2015), Spatial-temporal business partnership selection in uncertain environments, FME Transactions, Volume 43 No. 4, pp. 353-361. DOI: $10.5937 /$ fmet $1504353 \mathrm{~A}$.
[45] Abdollahzadeh, H., Varela, M. L. R., Atashgar, K., Putnik, G. D. (2015). Condition Based Maintenance Optimization for Multi-State Wind Power Generation Systems under Periodic Inspection, FME Transactions, 43(4), 2015, 319-327. DOI: 10.5937/fmet1504319A

[46] Ferreirinha, L., Baptista, S., Pereira, Â., Santos, A. S., Bastos, J., Madureira, A. M., \& Varela, M. L. R. (2019). An Industry 4.0 Oriented Tool for Supporting Dynamic Selection of Dispatching Rules Based on Kano Model Satisfaction Scheduling, FME Transactions, 47(4), 757-764.. DOI: $10.5937 /$ fmet1904757F.

[47] Alves, F., Varela, M. L. R., Rocha, A. M. A., Pereira, A. I., \& Leitão, P. (2019). A Human Centred Hybrid MAS and Meta-Heuristics Based System for Simultaneously Supporting Scheduling and Plant Layout Adjustment, FME Transactions, 47(4), 699-710. DOI: 10.5937/fmet1904699A.

\section{ПРЕГЛЕД ЛИТЕРАТУРЕ И ДИСКУСИЈА О ПРИСТУПИМА КОЛАБОРАТИВНОМ ДОНОШЕЊУ ОДЛУКА У ИНДУСТРИЈИ 4.0}

\section{Соуза А. Ц., Бертакини А. Ф., Куња К., Шавеш Р., Варела М. Л. Р.}

Данас се компаније суочавају са све већим нивоом конкуренције покушавајући да се прилагоде захтевима које намеће Индустрија 4.0, у погледу својих уобичајених димензија и основа, међу којима један који, иако се не спомиње тако често, такође изражава све већу видљивост и важност, у вези са колаборативношћу (колаборацијом, сарадњом), и тачније са колаборативним доношењем одлука и кораду. Тако је у овом раду извршена анализа еволуције публикација које су расположиве у последњој деценији о приступима колаборативног одлучивања, који варирају од приступа заснованих на математичким моделима до примене вештачке интелигенције и других врста приступа. Додатно, представљена је и дискусија о односу између колаборативног доношења одлука, конкурентног инжењеринга и димензија Индустрије 4.0. 